\title{
Governance of Citizen Participation and its Related Concepts: A Review of Literature
}

\author{
Michael Li \\ University of Massachusetts Boston, MA, USA \\ Email address: michael.lee.8034@gmail.com
}

\begin{abstract}
Keywords: Citizen participation, collaborative governance, public-private partnership, citizen coproduction
\end{abstract}

\begin{abstract}
This article reviews the concept of citizen participatory governance or citizen participation in public policy-making, a new mode of institutional arrangement increasingly becoming popular in many industrialized democracies. The governance of citizen participation may take different forms, and past studies used different terms in describing the concept. This article take a brief look at various forms of citizen participation (citizen participation in budgeting, collaborative governance, public-private partnership, and citizen coproduction of public service) and explain their concepts as demonstrated in prior research. In a nutshell, this article conclude that these various forms of citizen participation are not well conceptualized in the past literature and calls for future research in this research area with growing importance.
\end{abstract}

\section{INTRODUCTION}

In many countries, there is a growing movement in public administration and political science calling for a new mode of governance that brings governments and citizens together for public policymaking in order to address the democratic deficits and the growing citizenship (for instance, Ebdon and Franklin 2006; Fung 2006; Kelman and Hong 2012; Kelman et al. 2013; Hong 2015a). Over the past few decades, citizen participatory governance or citizen participation in public policy-making has become largely practiced as a means to achieve better democratic governance. The growing importance of citizen participation in policy-making decisions in different countries denotes the true realization of democracy. Earlier on, the only way that the public would participate in policy decisions was during the elections where they would vote for their political leaders. After that decision-making was left for the elected politicians not withstanding that they channeled their policy efforts to what they deemed important but not what the public deems importance. Citizen participation, however, eliminates the probability of political leaders making the wrong decisions for the community they serve since it ensures that the citizens are in the middle of the decision making process. Citizen participation in the modern age relates to improved democracy, more accountability for public offices and better decision-making process (Abel, 2007; Hong 2015a).

Citizen participation, however, continues to evoke arguments from different scholars. The arguments for citizen participation vouch for the vice for its numerous merits and the belief that citizen participation engages the citizens. Arguably and engaged citizenry are preferable to a passive citizenry (Hong 2015a). Citizen participation in formulating policies ensures that the policies are grounded on citizens preferences and that citizens understand the tough decisions that the government has to make for the public good (Fagence, 2014). Thus, citizen participation eliminates issues of citizen objection to the different policies since they are associated with the policies and know exactly what the policies are meant to achieve. Arguments against citizen participation argue that democratic theories are not comprehensive in establishing who, where and how the participation should be. Additionally, the opponents establish between democracy and citizen participation contesting the democratic threshold occupied by participation (Haruta, 2010).

The government involves citizen participation in different contexts and forms. For instance, citizen budgeting is a major component of the citizen participation, which involves factoring in citizens ideas and preferences on governments' financial resource allocation and their use for increased government effectiveness (Hong 2015a). Other forms of citizen participation include 
citizen co-production of public service, public-private partnership, and collaborative governance. That is, there are many similar but different forms of citizen participation in public policy-making discussed in past scholarship. Thus, the aim of this study is to review the concepts of each of the different modes of citizen participatory governance being discussed in the literature - citizen participation in budgeting, collaborative governance, public private partnerships, and citizen coproduction of public service - in order to advance our understandings about this democratic governance model. In other words, this paper looks into citizen participation in policy-making including the different perspectives it takes in governance (Irvin, 2004).

\section{CITIZEN PARTICIPATION IN BUDGETING}

Citizen participation is important to both the citizens and the government (Wampler 2007; Hong 2015a). The government can come up with informed development initiatives since the public contributes their opinion for important considerations during policy-making process. The citizens also have the chance to take part in the decision process by forwarding their needs, thoughts, and preferences for considerations. The entire process of citizen participation promotes democracy further pointing to the fact that the government is for the people and at the same time by the people (Irvin, 2004). Governments from all over the world continue involving the citizens in major decision such as budgetary allocations to further increasing its democratic levels (Ebdon \& Franklin, 2006). Additionally increased citizen participation lead to increased levels of accountability for public office holders hence the government resources are put into good use. Citizen participation takes different forms as practiced in the different contexts within which it is practiced.

In fact, citizen participation in budgeting is an important form of citizen participatory governance. The results of past studies tend to support the idea that citizen participation in budgeting offers a formal venue by which "policymakers can pursue the democratic ideal of opening policymaking to the citizenry while still maintaining an efficient process." (Hong 2015a, p.572). Probably, the best strengths of citizen participation in budgeting may be the fact that citizens have opportunities to reflect their preferences during a formal budgeting process, which distinguishes itself from a mere citizen advisory council.

\section{COLLABORATIVE GOVERNANCE}

Collaborative governance or collaborative management involves the government working with the people through its different agencies and players (Donahue 2004; Ansell and Gash 2011; Donahue and Zeckhauser, 2011; Kelman and Hong 2012; Kelman et al. 2013; Hong 2015b; Scott 2015). The specific forms of collaborative governance depends on the different context it takes and the team players involved (Kelman and Hong 2012; Kelman et al. 2013). The reasons behind the collaboration are also important as they chart the path for the practice (Zhang \& Yang, 2009). The collaborations have motivations behind them especially from the means, the motivation of actors, intended results and the expected income. Thus, collaborations take different forms and distinct dimensions from more hierarchical-types to more collaborative types (Moore and Koontz 2003; Kelman and Hong 2012; Kelman et al. 2013). Despites the wide array of different forms of governance, one may classify, based on the literature, the various forms of collaborations and summarize some common features as follow. First, collaborative governance might involve co-operation in an attempt to draw a commonality between the various stakeholders by aligning their practices together (Scott 2015). Second, collaboration may take the form of negotiations where the actors deliberate on the appropriate mechanism to unite their expectations. In negotiations, both of the actors (government and citizens) come together to compromise and certain trade-off issues that are of equal importance to each of them (Emerson, Nabatchi \& Balugh, 2012). Thirdly, collaborative governance may involve oversight roles where some actors are put in place to ensure proper coordination of different actors. The coordination process may also take the form of power and coercion where superior actors impose their preferences on weaker actors thereby forcing their outcome. Lastly, collaborative governance might involve collective plans where actors meet up and plan how to align their activities for a common goal in the future (O'flynn \& Wanna, 2008). 
Considering the various ways through which collaborative governance may take place, it is important to consider its deeper meaning to the citizenry. Collaboration usually involves two major sections that interplay to give it its meaning (Zodek 2008, Donahue 2004; Donahue and Zeckhauser 2011; Kelman et al. 2013). To start with, the scale of collaboration, which is the extent within which collaboration takes place, is used in explaining collaboration governance. The reasons behind the collaboration, the context, driving force and the arguments behind it are all important in considering the factors of successful collaboration. In this case, the different actors in collaboration come together after a consideration of the above factors (O'Leary and Bingham 2009). Collaborators make their collaboration decisions by considering their place, the situation, what they stand to gain, the changes that the collaboration will bring and their opinion or contribution in the collaboration (Worthington, Rask \& Minna, 2013).

In the case of citizen participation into governance, the public and the government benefit from the exercise. The government fosters collaborative effort as a way to ensure that it is performing as expected by the people. Most governments in the world have introduced public reforms where they shift the powers from the appointed or elected leaders to more functional administrative blocks (Mandell 2001). The administrative blocks employ the citizens in enhancing their performance as it has since been determined that collaborative governance enhances the government's performance (O'Leary and Bingham 2009; Kelman et al. 2013). For instance, the government through collaborating with the public is that it enables the policy makers to target the appropriate problems in the community, and acquire the stakeholders' permissions, opinions, or directions on how to tackle the problem. Collaboration leads to mutual learning and experience of both the government and the citizens since each of these actors plays an important role in the process (O'Leary and Bingham 2009; Wampler 2007). Collaboration improves specialization between the actors by marking out roles for each actor and through a combination of various skills and capacities relevant to the collaboration exercise. Collaboration, however, may experience challenges especially when senior officials have to deal with the public (Kelman and Hong 2012). The reason behind this argument is that the public officials might not see the need to engage the public when they know that the outcome will result in their losing of power to the collaboration effect. Such political leaders might also lead to dysfunctional collaboration governance. The leaders might use their authority to coerce or force the public to do which they are not comfortable with which is not covered by the collaboration exercise (Ansell \& Gash, 2008).

\section{PUBLIC-PRIVATE PARTNERSHIPS}

Public-private partnerships are legally binding contracts made by the government with businesses involving the provisions of goods or services with the government transferring the real risks and responsibilities among the contract parties. Public Private Partnerships (or simply PPPs) involves an interplay between the public and the private and characterized by a high level of risk for both the public and the private (Hemming, 2006; Engel et al. 2010; Hong 2015b). However, PPPs are aimed at transferring much of the business risks from the public to the private. The transfer of risks is, however, positive from a social welfare point of view since it provides a mutual benefit for both the public and the partnerships (see Hong 2015b for somewhat different perspectives). For instance, the private business experience financial gains while the government is covered for risks in its projects and services. Additionally PPPs ensures that the best capabilities for both the public and private sectors are utilized (Partnerships 2003).

PPPs are important institutional tools for the government, the citizens, and the private sector. PPPs lead to an effective service delivery, cost efficiency, reduction of risks, put assets to better use, increase the investment in the infrastructure sector, reduce risks for the public sector, and improve budget certainty (Engel et al. 2010; see also Hong 2015b). The PPPs also binds the services providers or assets manager for a certain duration, which ensures a continuum of high-quality services during the agreed time. For example, if a company is contracted to construct and manage a road for twenty years, then the road will be kept good for those twenty years with prompt repair in case of wear and tear. PPPs are also important to the public sector since they expand the long-term 
business investment opportunities and maximize profits by utilizing their highly effective personnel to finish projects on time (Custos \& Reights, 2010).

\section{CITIZEN CO-PRODUCTION OF PUBLIC SERVICE}

Citizen co-production of public service denotes that the public is involved in producing public services that influence the lives of the citizenry in general (Kiser and Percy 1980; Whitaker 1980; Levine 1984; Boyle \& Harris 2009; Hong 2015c). Citizens work alongside public service agencies in producing public services, which they also consume. Thus, citizens are both producers and consumers of the public service (Asquire, Street \& Square 2012; Boyle \& Harris 2009; Hong 2015c). Citizen coproduction is a complex and relatively new concept, which has a lot of dimensions left out for future research. For instance, co-production raises a number of questions on its nature including the difference between individual and group co-production, and the driving force behind the citizen coproduction and many more (Pestoff, 2009). Citizen's involvement in providing the public service improve the quality of such service since it incorporates user professionalism in the service creation process. Consequently, differentiated, low costs, increased choices, and presence of more responsive services emerge from citizen co-production. Thus far, however, the concept of citizen co-production has not been extensively researched and the present scholarship lacks conclusive statements regarding the same (Loffler et al., 2008). Therefore, this paper calls for further research in this important area in the form of both conceptual and empirical studies.

\section{CONCLUSION}

In sum, citizen participatory governance in public policy-making is a new governance mode, increasingly becoming important not only in scholarship but also in government practice. Scholars in different fields including political science, sociology, economics, and public administration have developed a number of different concepts of citizen participatory governance that are closely related one another. But, previous studies have done relatively little in explaining how they differ and how they relate to one another. This is an important omission, and this article tried to introduce the concepts of various modes of this new governance model.

As we have discussed, citizen participation makes the policy-making process effective since the government can make well-informed decisions drawn from the citizens (Hong 2015a). The citizens, on the other hand, pass their preferences and needs to the policy-makers ensuring that the policies are better placed to achieve the necessary development and growth in a country. The various forms of citizen participation, collaborative governance, public-private partnerships, and citizen co-production of public service are all important in ensuring that the right relationship between citizens and public service agents is created. Additionally, the citizen participation platforms enable the citizens and the governments to work together to propel the wheel of democracy and well-supported and informed development.

Before we conclude, it is important to note once again the growing importance of citizen participatory governance in many countries (Wampler 2007; Hong 2015a). This increasing emphasis on this new mode of governance may show the significant democratic deficits experienced in many countries, but it may also have to do with the rapidly developing new information technologies such as social media that has a great potential for empowering normal citizens (Hong 2013; Hong and Nadler 2013; Gainous and Wagner 2014). If the growing importance of citizens' roles in policy-making has something to do with the advance in new information technologies, then it means that this trend will continue in the future. For this reason, we strongly believe that citizen participatory governance will become even more important in both research and practice, just as we expect that new information technologies will keep its development. We look forward to seeing a substantial advance in this important area of research in the years to come. 


\section{References}

[1] Abels, G. (2007). Citizen involvement in public policy-making: Does it improve democratic legitimacy and accountability? The case of pTA. Interdisciplinary Information Sciences, 13(1), 103-116.

[2] Ansell, C., \& Gash, A. (2008). Collaborative governance in theory and practice. Journal of Public Administration Research and Theory, 18(4), 543-571.

[3] Asquer, A., Street, T., \& Square, R. (2012).Co-investment in the Co-production of Public Services: Are Clients Willing to Do It?.

[4] Boyle, D., \& Harris, M. (2009). The challenge of co-production. London, New Economics Foundation.

[5] Custos, D., \& Reitz, J. (2010). Public-Private Partnerships. The American Journal of Comparative Law, 555-584.

[6] Donahue, John (2004). On Collaborative Governance, Corporate Social Responsibility Initiative Working Paper No. 2, Cambridge, MA: John F. Kennedy School of Government, Harvard University

[7] Donahue, J. D., and Zeckhauser, R. J. (2011). Collaborative Governance: Private Roles for Public Goals in Turbulent Times. Princeton University Press.

[8] Ebdon, C., \& Franklin, A. L. (2006). Citizen participation in budgeting theory. Public Administration Review, 66(3), 437-447.

[9] Emerson, K., Nabatchi, T., \& Balogh, S. (2012). An integrative framework for collaborative governance. Journal of Public Administration Research and Theory, 22(1), 1-29.

[10] Engel, Eduardo, Ronald Fischer, and Alexander Galetovic. (2010). "The Basic Public Finance of Public-Private Partnerships. " Journal of the European Economic Association.

[11] Fagence, M. (2014). Citizen participation in planning. Elsevier.

[12] Fung, A. (2006). Varieties of Participation in Complex Government, Public Administration Review, Vol. 66, Iss. s1, pp. 66-75.

[13] Gainous, Jason, and Wagner, K. M. (2014). Tweeting to Power: The Social Media Revolution in American Politics. New York and Oxford: Oxford University Press

[14] Haruta, C., \& Bianca, R. A. D. U. (2010). Citizen Participation in the Decision Making Process at Local and County Levels in the Romanian Public Institutions. Transylvanian Review of Administrative Sciences, 6(31), 76-92.

[15] Hemming, R. (2006). Public-private partnerships. International Monetary Fund.

[16] Hong, S. (2013). Who Benefits from Twitter? Social Media and Political Competition in the U.S. House of Representatives. Government Information Quarterly 30 (4): 464-72. doi:10.1016/j.giq.2013.05.009.

[17] Hong, S., D. Nadler (2012) Which candidates do the public discuss online in an election campaign?: The use of social media by 2012 presidential candidate salience. Government Information Quarterly. Vol. 29: 455-461.

[18] Hong, S. (2015a). Citizen Participation in Budgeting: A Tradeoff Between Knowledge and Inclusiveness?, Public Administration Review, Volume 75, Issue 4, July/August 2015, p. 572-582. DOI: 10.1111/puar.12377

[19] Hong, S. (2015b). When Does a Public-Private Partnership (PPP) Lead to Inefficient Cost Management?: Evidence from the Korean Urban Rail Transit System, Public Money and Management, forthcoming

[20] Hong, S. (2015c). Representative Bureaucracy, Organizational Integrity, and Citizen Coproduction: Does an Increase in Police Ethnic Representativeness Reduce Crime? Journal of Policy Analysis and Management, forthcoming 
[21] Irvin, R. A., \& Stansbury, J. (2004). Citizen participation in decision making: is it worth the effort? Public administration review, 64(1), 55-65.

[22] Kelman, S., and Hong, S. (2012). Hard, Soft, or Tough Love: What Kinds of Organizational Culture Promote Successful Performance in Cross-Organizational Collaborations? HKS Faculty Research Working Paper Series, RWP12-005. John F. Kennedy School of Government, Harvard University.

[23] Kelman, S., Hong, S., \& Turbitt, I. (2013). Are There Managerial Practices Associated with the Outcomes of an Interagency Service Delivery Collaboration? Evidence from British Crime and Disorder Reduction Partnerships. Journal of Public Administration Research and Theory, 23(3), 609-630. http://doi.org/10.1093/jopart/mus038

[24] Kiser, L.L. and Percy, S.L. (1980), The concept of coproduction and its implications for the public service delivery. Working paper No. 80-6 Bloomington, IN: Indiana University.

[25] Levine, C.H., (1984), Citizenship and Service Delivery - the Promise of Co-production, Public Administration Review, Vol.44, pp.178-87.

[26] Löffler, E., Parrado, S., Bovaird, T., \& Van Ryzin, G. (2008). If you want to go fast, walk alone. If you want to go far, walk together. Citizens and the co-production of public services. Report to the EU Presidency. Ministry of Finance, Budget and Public Services, Paris.

[27] Mandell, M. P. (2001). Collaboration through network structures for community building efforts. National Civic Review, 90, 279-288.

[28] Moore, E., \& Koontz, T. (2003). A typology of collaborative watershed groups: Citizenbased, agency-based, and mixed partnerships. Society \& Natural Resources, 16, 451-460.

[29] O'Flynn, J. L., \& Wanna, J. (2008). Collaborative Governance: A New Era of Public Policy in Australia?. Australia and New Zealand School of Government Series.

[30] O'Leary, R., \& Bingham, L. B. (2009). The collaborative public manager: New ideas for the twenty-first century. Washington, DC: Georgetown University Press.

[31] Partnerships, B. C. (2003). Introduction to Public-Private Partnerships. British Columbia, Canada.

[32] Pestoff, V. (2009). The Third Sector, Citizen Participation and Co-Production of Personal Social Services in Sweden-towards a new paradigm. Annals of Public and Cooperative Economics.

[33] Scott, T. (2015). Does Collaboration Make Any Difference? Linking Collaborative Governance to Environmental Outcomes. Journal of Policy Analysis and Management, Vol. 34, No. 3, 537-566 (2015)

[34] Worthington, R., Rask, M., \& Minna, L. (2013). Citizen participation in global environmental governance. Routledge.

[35] Zadek, S. (2008). Collaborative governance: The new multilateralism for the 21st century. Global development, 2.

[36] Zhang, Y., \& Yang, K. (2009). Citizen participation in the budget process: The effect of city managers. Journal of Public Budgeting, Accounting \& Financial Management, 21(2), 289.

[37] Wampler, B. (2007). Participatory Budgeting in Brazil: Contestation, Cooperation, and Accountability. University Park: Penn State University Press.

[38] Whitaker, G. P. (1980). Co-production: citizen participation in service delivery, Public Administration Review, 40, pp. 240-246. 